\title{
Construct Measurement and Validation of Organizational Citizenship Behavior in Educational Context: Demographic Differences
}

\section{Deepika Gupta*}

Punjab Technical University, Punjab, India

Article Type: Article

Article Citation: Deepika Gupta, Construct Measurement and Validation of Organizational Citizenship Behavior in Educational Context: Demographic Differences, ISBR Management Journal. 2021; 6(01), 5-15. D0I: 10.52184/ isbrmj.v6i1.109

Received date: March 20, 2021

Accepted date: April 25, 2021

*Author for correspondence: Deepika Gupta Deepika.2615@ gmail.com 9 Punjab Technical University, Punjab, India

\begin{abstract}
Though organizational citizenship behavior (OCB) is not enforceable by any organization, it is a voluntary behavior of employees which promotes the effective functioning of any organization. Organizational citizenship behavior is a multidimensional concept. Due to individual behavior and prevailing circumstances, OCB may vary from one organization to another organization or from one section to another section. In line with that, the present study explores the instrument for assessing organizational citizenship behavior in primary and high school teachers in Amritsar. The study has used a descriptive research design and a quantitative approach. The analysis of the data was made with the help of the exploratory and confirmatory factor analysis. The analysis of the data clearly revealed the understanding of different dimensions of organizational citizenship behavior in the context of school education.
\end{abstract}

Keywords: Organizational Citizenship Behavior (OCB), Exploratory and Confirmatory Factor Analysis

\section{Introduction}

To accomplish school-related objectives formal job description cannot cover the entire range of behaviors so it is necessary to show extra-role behavior by teachers (Zeinabadi, 2010). Inherently, the success of schools depends upon teachers' readiness to work above and beyond the specific role requirement to attain the organizational goals. These nondirected behavior shown by teachers are known as organizational citizenship behavior (Bogler \& Somech, 2004; Duyar \& Normore, 2012; DiPaola \& Tschannen-Moran, 2001; Sweetland \& Hoy, 2000; Somech \& Oplatka, 2014). OCB helps in increasing the efficiency and effectiveness of schools by providing resources for constructive purposes, assist in the coordination and make teachers capable of adopting changes within and outside the organization (DiPaola \& Hoy, 2005; Somech \& Oplatka, 2014; Duyar \& Normore, 2012; Sesen $\&$ Basim, 2012). Some of the researchers investigated that to check the effectiveness 
of schools, demographic variables play an important role like location, type of schools (Rumberger \& Thomas, 2000), and type of gender (Kidder \& Parks, 2001; Organ \& Ryan, 1995). Although a large corpus of affirmation on the relationship between OCB and demographic characteristics was available but still it is unevenly distributed across different countries and that too in India. The results of this study may therefore be beneficial for the researchers and educators for future research.

\section{Organization Citizenship Behavior}

Organ (1988) defined OCB as "Individual behavior that is discretionary, not directly or explicitly recognised by the formal reward system and that in the aggregate promotes the effective functioning of the organization". (Organ, Podsakoff \& MacKenzie, 2006; Turnipseed \& Rassuli, 2005; Williams \& Anderson, 1991). Organ (1997) refined this definition, conceptualising "OCB as any form of performance that supports the social or psychological environment in which the work tasks are embedded". These definitions are commonly used by many researchers in both education and non-education sectors to measure OCB. It is an employee behavior which is positive in nature and strongly contributes to increasing the efficiency and performance of the organization (Kidwell, Mossholder, \& Bennett, 1997; Organ, 1988, 1990; Podsakoff, MacKenzie, Paine \& Bachrach, 2000; Podsakoff, MacKenzie, Moorman, \& Fetter, 2009; Fisher, McPhail \& Menghetti, 2010). In 1983, Bateman \& Organ instigate the term “Organizational citizenship behavior”. Different litterateurs have different views about OCB dimensions. There were thirty different forms of OCB as identified from the literature (Podasakoff et al., 2000). Despite of differences in dimensions, seven common dimensions on OCB were presented by Podsakoff et al., (2000): Helping Behavior, Sportsmanship, Organizational Loyalty, Organizational Compliance, Individual Initiative, Civic Virtue, and Self Development. Farh, Zhong \& Organ (2004) categorized nine major dimensions of OCB: Altruism, Conscientiousness, Sportsmanship, Courtesy, Civic Virtue, Functional Participation, Advocacy Participation, Loyalty and Voice. In (1983) Smith, Organ \& Near had given two different dimensions of OCB i.e. altruism and generalized compliance (also called conscientiousness). Later Organ (1988) highlighted the five distinct categories of discretionary behavior and explains how each one helps to improve efficiency in the organization. The five-dimensional structure proposed by Organ (1988) was the most consensual.

1. Altruism is a voluntary behavior in which an employee assists his co-workers in completing his task under unusual circumstances (Smith et al., 1983).

2. Conscientiousness is a discretionary behavior conducted by the employee to execute their organizational responsibilities in a way that goes well beyond the determined job description (MacKenzie, Podsakoff \& Fetter, 1993).

3. Sportsmanship is another important dimension of OCB. It is a willingness of employees to tolerate the inexorable nuisance and burden of work without any complain, appeals, accusations, and offense, thus protecting the organizational spirit and maintaining a synergistic environment at the workplace for the attainment of objectives (Organ \& Ryan, 1995; Organ, 1988, 1990; Podsakoff et al., 2000). 
4. Courtesy is a discretionary behavior in which a person is intended to prevent jobrelated problems with their colleagues and/or workgroups (Organ 1988; Podsakoff et al., 1990; Law, Wong \& Chen, 2005). It also includes all the behaviors which helps in avoiding the problem to arise.

5. Civic Virtue is a sub-dimension of organizational citizenship behavior. It is a voluntary behavior carried out by a person in which he/she responsibly engages in the activities about the benefit of the organization (Organ 1988; Podsakoff et al., 1990; Law et al., 2005).

\section{OCB in Teaching Context}

As teaching is the largest profession in the world, OCB in the teaching context is also important. As the in-role requirements for teachers are unalterable (for e.g. Setting timetables, curriculum etc.) but still they retain a high level of sovereignty (Forrester, 2000). Many researchers have stated clearly that teachers' effectiveness can be achieved not only by carrying out the core jobs successfully but also extra-role behavior for students and schools (Bogler \& Somech, 2004). OCB, also known as "good soldier syndrome" (Organ, 1988; Smith et al., 1983), a multi-dimensional construct (Walz \& Niehoff, 1996; Law et al., 2005), a behavior that resulted in positive organizational consequences. Helping colleagues, volunteering, unconventional attitude, and completing a task on time (Organ, 1988) are some of the examples of OCB. With regards to educational institutions, literature suggested that the teachers in successful schools do not just focus on the activities assigned to them, but also ensure that they go out of the way and do things above and beyond the expectations set from them so that the performance of students was also above par (DiPaola \& Hoy, 2005). Practically schools had to make significant efforts beyond their formal functional requirements (Bogler \& Somech, 2004; Somech \& Bogler, 2002). Studies have shown the positive consequences of OCB on schools like the success of students (DiPaola \& Hoy, 2005; Oplatka, 2009); coordination among staff members, and making the workplace more couthy (Podsakoff et al., 2000). Many researchers have analyzed and explored the salient forms of OCB in different sectors all over the world but focus on OCB in an educational context was scarce (Jimmieson, Hannam \& Yeo, 2010; Oplatka \& Stundi, 2011) and that too in Indian context. The main objective of the work is to fill the void and to contribute towards the development of knowledge on OCB by examining the factorial structure in primary and high schools of Punjab and validate an instrument of measure particularly designed to collect the data for this study. Further, the study focuses on finding a significant difference in OCB based on gender and type of school.

\section{Participants}

The present study was based on primary data collected from the Amritsar district. To represent the public education sector, 300 primary and high school teachers were selected. The sample consisted of 108 males and 192 females teachers. The questionnaire was 
personally administered by the teachers of primary and high schools. They were informed of the purposes of the study and confidentiality was ensured.

\section{Measurement Tools}

Podsakoff et al. (1990) scale of 24 item statements for Organizational Citizenship Behavior was used for analysing the behavior of teachers working in primary and high schools. Statements were evaluated on a five-point Likert-type scale ranging from 1 (strongly disagree) to 5 (strongly agree). The data were organized, processed, and verified. Descriptive Analysis and statistical techniques like mean, standard deviation, Cronbach's alpha was applied to check reliability of data. Explanatory and confirmatory factor analysis was performed, which confirmed the construct validity of components of the study.

\section{Analysis and Interpretation}

Data analysis was performed using SPSS 21 and AMOS 20 statistics packages. The participation of the study reported moderately high levels of courtesy with a mean score of 4.40 and a standard deviation of .50 indicating the discretionary behavior helps in preventing work-related problems. The overall mean score of the participants' Altruism was a little high with a mean score of 4.39 with a standard deviation of .59, showing the participant's willingness to help their fellow employees with work-related problems. Also, the participants reported a score of civic virtue with an overall mean score of 4.05 and a standard deviation of .65 , indicating the participants attend organizational functions and meetings voluntarily. The overall mean score of the participants' sportsmanship was 4.00 with a standard deviation of .69 , indicating the considerate behavior that helps in completing work without complaining and tolerating the expected inconvenience. The participants of the study also reported a slightly high level of conscientiousness with a mean score of 4.39 and standard deviation of .55 indicating the participants perform well beyond the minimum roles and responsibilities.

\subsection{Exploratory Factor Analysis}

Since the results of the Kaiser-Meyer-Olkin Measure of Sampling Adequacy (0.892) and Bartlett's Test of Sphericity $($ Sig $<0.5)$ indicating that the data was appropriate for factor analysis (Kaiser \& Rice, 1974; Hair, Black, Babin, Anderson \& Tatham 2006).

The principal component analysis identified and estimated the presence of five factors with Eigen values of more than 1 . These 5 factors explained a total of $72.464 \%$ variance. Reliability analysis was performed to check the internal consistency of the scale (Cronbach, 1951). The overall alpha value of the OCB scale was $(\alpha=0.894)$ which was in the acceptable range (Nunnally \& Bernstein, 1994; Bland \& Altman, 1997). 
TABLE 1. Factor structure for organizational citizenship behavior.

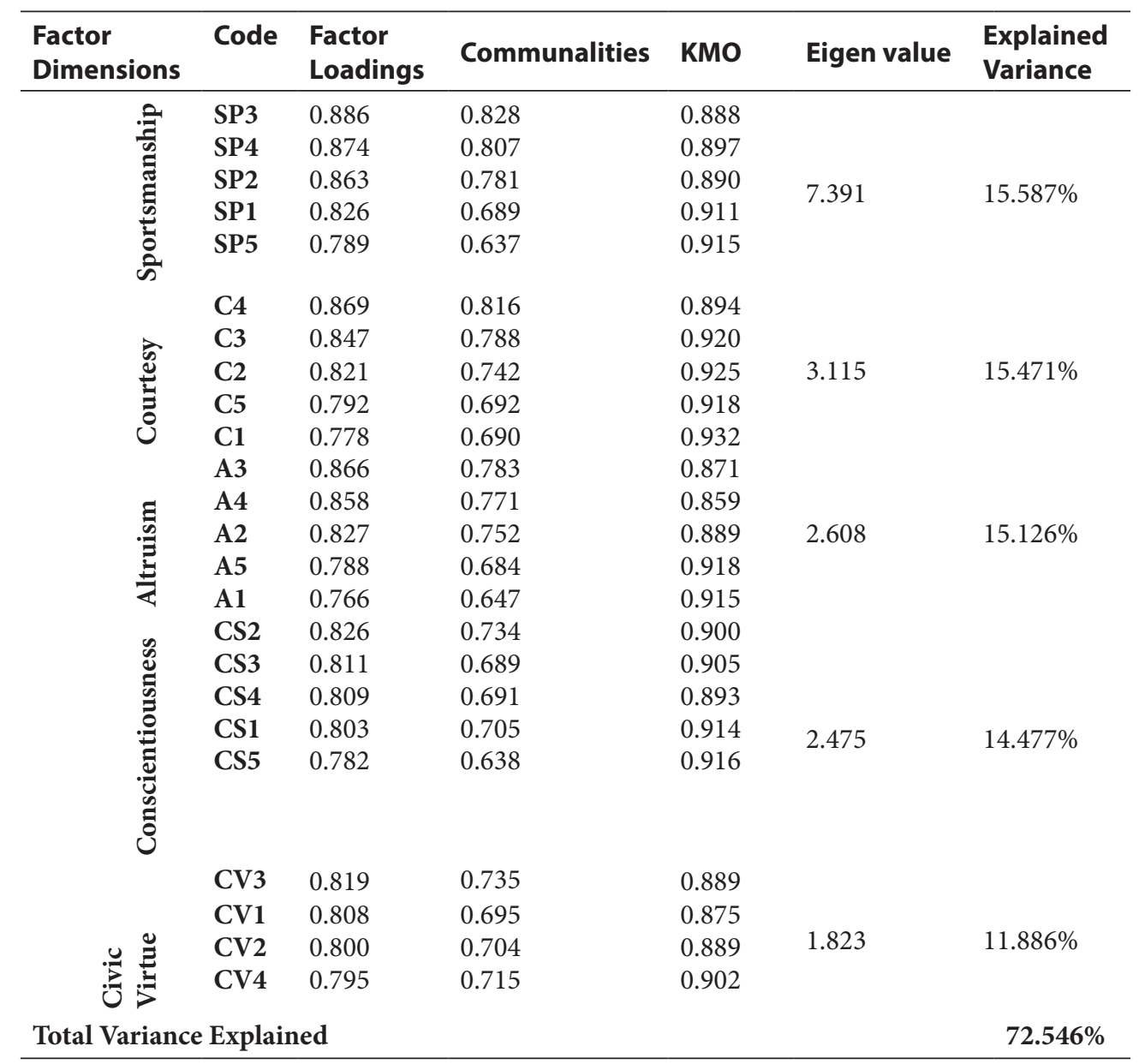

\subsection{Validity Testing Using Confirmatory Factor Analysis}

The construct validity of OCB scale was tested using confirmatory factor analysis. The CFA diagram indicates the construct loading of different statements related to the respective construct in the scale. The result indicates that all the construct loadings are found to be more than 0.5 . Hence, it can be concluded that each variable has significant correlation to the extracted factors.

The result indicates the Pearson Correlation Statistic between the extracted factors is found to be positive but not very high. The low level of correlation between the extracted factors represents the presence of discriminant validity amongst the extracted factors. The results for the factor model revealed the following fit indices which have fulfilled the requirement of the conventional standards for GFI, CFI, IFI. 


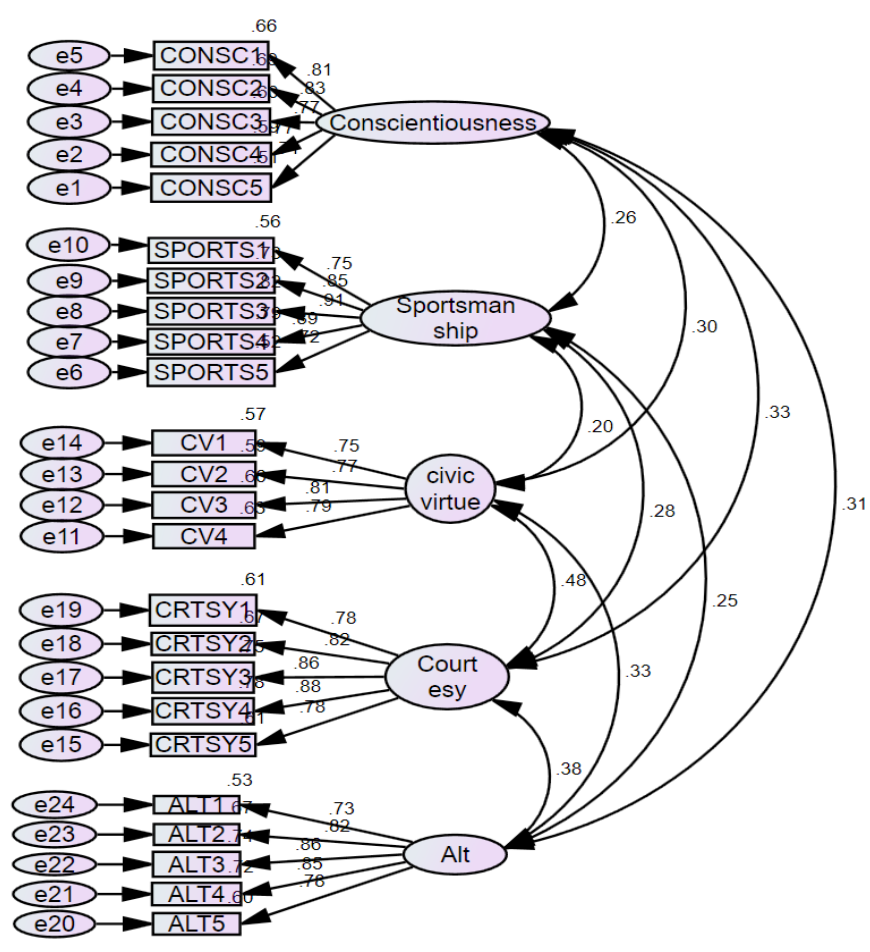

FIGURE 1: CFA model of organizational citizenship behavior

TABLE 2. Model fit statistics.

\begin{tabular}{lcl}
\hline Index & Values & Accepted Range \\
\hline$\chi^{2} / \mathrm{df}$ & 2.51 & $<3$ (Hair, Black, Babin \& Anderson, 2010) \\
RMSEA (Root mean square error of & 0.45 & $<0.05$ (Browne \& Cudeck, 1993) \\
approximation) & & \\
GFI (Goodness of fit index) & 0.937 & (Forza \&Filippini, 1998) \\
CFI(Comparative fit index) & 0.968 & (Hair et al., 2010) \\
IFI (Incremental fit index) & 0.968 & (Hair et al., 2010) \\
\hline
\end{tabular}

The composite reliability (CR), average variance extracted (AVE), maximum shared variance (MSV) was estimated for all the extracted factors shown below in the Table 3. The result indicated that the CR of the extracted factors was found to be greater than 0.7 (Fornell \& Larcker, 1981) and AVE was found to be greater than 0.5 (Hair et al., 2010). Hence, it can be concluded from the study the convergent validity of the factors was ensured. Further, the result indicated that the average variance extracted was found to be greater than MSV which ensures the presence of discriminant validity. 
TABLE 3. Convergent and discriminant validity statistics.

\begin{tabular}{lllll}
\hline DIMENSIONS & CR & AVE & MSV & ASV \\
\hline Courtesy & 0.914 & 0.682 & 0.227 & 0.139 \\
Conscientiousness & 0.886 & 0.608 & 0.110 & 0.091 \\
Sportsmanship & 0.914 & 0.683 & 0.076 & 0.059 \\
Civic Virtue & 0.863 & 0.612 & 0.227 & 0.166 \\
Altruism & 0.904 & 0.654 & 0.143 & 0.102 \\
\hline
\end{tabular}

Source: Author's calculation based on primary data.

Note : Primary data has been obtained from Amritsar districts of Punjab

The data for the study was collected from the teachers belonging to two different groupsprimary and high schools. Statistics revealed that in primary school, teacher's courteous behavior $(X=4.46)$ is associated with numerically highest mean whereas in high schools, it was found that teacher's altruism behavior $(X=4.44)$ has shown the numerically highest mean.

TABLE 4. Variance in dimensions of OCB based on type of school.

\begin{tabular}{llllllll}
\hline Dimensions & \multicolumn{2}{l}{ Primary Schools } & \multicolumn{2}{l}{ High Schools } & \multicolumn{2}{l}{ Values } \\
\hline & Mean & S.D & Mean & S. D. & T-Values & P-Values & D.F \\
Altruism & 4.33 & 0.525 & 4.44 & 0.591 & -1.712 & 0.088 & 298 \\
Courtesy & 4.46 & 0.452 & 4.35 & 0.563 & 0.053 & 0.068 & 298 \\
Civic Virtue & 4.03 & 0.638 & 4.06 & 0.680 & 0.085 & 0.769 & 298 \\
Sportsmanship & 4.01 & 0.667 & 3.97 & 0.722 & 0.566 & 0.572 & 298 \\
Conscientiousness & 4.41 & 0.540 & 4.36 & 0.561 & 0.777 & 0.438 & 298 \\
\hline
\end{tabular}

Source: Primary data has been obtained from Amritsar districts of Punjab.

Note : SD (Standard Deviation); DF (Degree of Freedom)

The result of independent sample $t$ - test indicated no statistically significant difference in $p$-values of the five different dimensions between teachers of primary and high schools.

TABLE 5. Variance in dimensions of OCB based on gender.

\begin{tabular}{llllllll}
\hline Dimensions & Males & \multicolumn{7}{l}{ Females } & \multicolumn{2}{l}{ Values } \\
& Mean & S.D & Mean & S. D. & T-Values & P-Values & D.F \\
Altruism & 4.37 & 0.542 & 4.40 & 0.572 & -0.473 & 0.637 & 298 \\
Courtesy & 4.36 & 0.545 & 4.43 & 0.492 & -1.031 & 0.303 & 298 \\
Civic Virtue & 4.12 & 0.694 & 4.00 & 0.635 & 1.512 & 0.132 & 298 \\
Sportsmanship & 4.00 & 0.687 & 3.98 & 0.699 & 0.125 & 0.901 & 298 \\
Conscientiousness & 4.49 & 0.529 & 4.33 & 0.554 & 2.434 & 0.016 & 298 \\
\hline
\end{tabular}

Source: Primary data has been obtained from Amritsar districts of Punjab. Note : SD (Standard Deviation); DF (Degree of Freedom)

Hence, with 95 percent confidence level, it can be concluded that the null hypothesis of no significance difference between primary and high school teachers with respect to OCB can be accepted. In Table 5, Statistics revealed that males were showing more conscientiousness behavior $(X=4.49)$ whereas female teachers were associated with more 
courteous behavior $(X=4.43)$. The research has found statistically significant difference at $\mathrm{p}<0.05$ level in conscientiousness $(\mathrm{t}=-2.434, \mathrm{p}=0.016)$. Hence, with 95 percent confidence level, it can be concluded that null hypothesis of no significance difference between males and females with respect to conscientiousness can be rejected.

\section{Discussion/Conclusion}

The present study assesses the OCB in the educational system. OCB is very much important because it helps the schools to make the changes more adaptable for smooth and effective functioning in long run (DiPaola \& Tschannen-Moran, 2001). The study has used a descriptive research design and a quantitative approach. In general, participants perform voluntary tasks, prevent work-related problems, support organizational functions and meetings without any complaints, and tolerate expected inconvenience. The present study tested five dimensions of OCB- altruism, conscientiousness, courtesy, civic virtue, and sportsmanship in an educational context. Based on the results of validity and reliability, the OCB scale showed a good fit with the data. All these factors explained overall variance of 72.546 percent. This showed that teachers can work with each other voluntarily beyond their specific job description. Results also stated that OCB scale with twenty-four statements is suitable to check teachers behavior in Amritsar district. Therefore, the present study has confirmed previous research that depicts OCB as a five-factor model (Jepsen \& Rodwell, 2006). The findings of the study revealed that the participants of the primary school displayed the highest mean score in case of courtesy whereas teachers working in high school displayed highest mean in altruistic behavior. The result of independent sample t- test indicated no statistically significant difference in p-values of the five different dimensions between teachers of primary and high schools. Further descriptive analysis of the data revealed that female teachers were more engaged in courteous behaviors compared to male teachers whereas male teachers were more engaged in conscientious behavior. The result is consistent with the studies have been done previously (Heilman \& Chen, 2005; Kidder \& McLean Parks, 2001). Additionally, the research has found a statistically significant difference at $p<0.05$ level in conscientiousness w.r.t. gender. This study has successfully achieved its objective of outlining the structure of teachers' OCB, which are essential for the overall growth of the school, students, and the self-development of the teachers.

\section{Limitations and Future Extension}

Despite the strengths of this paper and large sample size $(n=300)^{\prime}$, there were few limitations that must be taken care. The first limitation of this study was that it was conducted in district Amritsar, so its results could be generalized only for Amritsar and not for entire education sector in India. In this we had taken five dimensions of OCB which might lead to a neglect of other possible dimensions. Self-rating to measure OCB was another drawback. Many researchers now prefer to measure OCB with other ratings, such as 
supervisor or colleague, rather than with self-rating after Organ \& Ryan's (1995) study. The choice of collecting data with self-reported measures may lead to the phenomenon of social desirability bias in common variances liable to overestimate the research results (Spector, 1987). Furthermore, as this is a cross sectional research which means that these results might not be the same if the study was repeated at a different time. Despite these limitations, the study could still yield useful insights into the relationships among the variables considered, and thus make important contributions to the literature. As for future research, different measures should be used for OCB calculations (peer ratings) to get better results. Other variables like job satisfaction, task performance, justice, commitment should also be included to improve the results. Research should be conducted in primary, secondary as well as higher education with greater sample size in different geographical areas while comparing urban and rural schools.

\section{References}

Bateman, T. S., \& Organ, D. W. (1983). Job satisfaction and the good soldier: The relationship between affect and employee citizenship. Academy of Management Journal, 26(4), 587-595. doi: $10.2307 / 255908$

Bernstein, I. H., \& Nunnally, J. C. (1994). Psychometric theory.McGraw-Hill: New York.

Bland, J. M.,\& Altman, D. G. (1997). Statistics notes: Cronbach's Alpha. British Medical Journal, 314 (7080), 572. doi: 10.1136/bmj.314.7080.572

Bogler, R., \& Somech, A. (2004). Influence of teacher empowerment on teachers' organizational commitment, professional commitment and organizational citizenship behavior in schools. Teaching and Teacher Education, 20(3), 277-289. doi: 10.1016/j.tate.2004.02.003

Browne, M. W., \& Cudeck, R. (1993). Alternative ways of assessing model fit. Sociological Methods \& Research, 21(2), 230-258. doi: 10.1177/0049124192021002005.

Byrne, B. M. (1998). Structural equation modeling with LISREL, PRELIS, and SIMPLIS: Basic concepts, applications, and programming. Psychology Press: New York.

Cronbach, L. J. (1951). Coefficient alpha and the internal structure of tests. Psychometrika, 16(3), 297-334. doi: 10.1007/BF02310555

Dipaola, M., \& Tschannen-Moran, M. (2001). Organizational citizenship behavior in schools and its relationship to school climate. Journal of school Leadership, 11(5), 424-447.doi: $10.1177 / 105268460101100503$

DiPaola, M. F., and Hoy, W. K. (2005). Organizational citizenship of faculty and achievement of high school students. The High School Journal, 88(3), 35-44.

Duyar, I., \& Normore, A. H. (Eds.). (2012). Discretionary behavior and performance in educational organizations: The missing link in educational leadership and management. Emerald Group Publishing: West Yorkshire.

Farh, J. L., Zhong, C. B., \& Organ, D. W. (2004). Organizational Citizenship Behavior in the People's Republic of China. Organization Science, 15(2), 241-253.doi:

Fisher, R., McPhail, R., \& Menghetti, G. (2010). Linking employee attitudes and behaviors with business performance: a comparative analysis of hotels in Mexico and China. International Journal of Hospitality Management, 29(3), 397-404. doi: 10.1016/j.ijhm.2009.10.021

Fornell, C., \& Larcker, D. F. (1981). Structural equation models with unobservable variables and measurement error: Algebra and statistics. Journal of Marketing Research, 18(3), 382-388. doi: $10.2307 / 3150980$ 
Forrester, G. (2000). Professional autonomy versus managerial control: The experience of teachers in an English primary school. International Studies in Sociology of Education, 10(2), 133-151.doi: $10.1080 / 09620210000200056$

Hair, J.F., Black, W.C., Babin, B.J., and Anderson, R.E. (2010). Multivariate data analysis. Prentice Hall: New Jersey.

Hair, J. F., Black, W. C., Babin, B. J., Anderson, R. E., \& Tatham, R. L. (2006). Multivariate data analysis: Pearson Prentice Hall: New Jersey, pp. 1-816.

Heilman, M. E., \& Chen, J. J. (2005). Same behavior, different consequences: reactions to men's and women's altruistic citizenship behavior. Journal of Applied Psychology, 90(3), 431-441. doi: 10.1037/0021-9010.90.3.431

Jimmieson, N. L., Hannam, R. L., \& Yeo, G. B. (2010). Teacher organizational citizenship behaviors and job efficacy: Implications for student quality of school life. British Journal of Psychology, 101(3), 453-479.doi: 10.1348/000712609X470572

Jepsen, D. M., \& Rodwell, J. J. (2006, January). A side-by-side comparison of two organizational citizenship behavior models and their measures: Expanding the construct domain's scope. Proceedings of the 11Th Annual Conference of Asia-Pacific Decision Sciences Institute Conference, 381-384.

Kaiser, H. F., \& Rice, J. (1974). Little jiffy, mark IV. Educational and Psychological Measurement, 34(1), 111-117.doi: 10.1177/001316447403400115

Kidder, D. L., \& Parks, J. M. (2001). The good soldier: who is s (he)?. Journal of Organizational Behavior: The International Journal of Industrial, Occupational and Organizational Psychology and Behavior, 22(8), 939-959. doi: 10.1002/job.119

Kidwell, R. E., Mossholder, K. W., \& Bennett, N. (1997). Cohesiveness and organizational citizenship behavior: A multilevel analysis using work groups and individuals. Journal of Management, 23(6), 775-793.doi: 10.1016/S0149-2063(97)90029-5

Law, K. S., Wong, C. S., \& Chen, Z. G. (2005). The construct of organizational citizenship behavior: Should we analyze after we have conceptualized?. In Handbook of organizational citizenship behavior: A review of good soldier activity in organizations. Nova Science Publishers Inc..

MacKenzie, S. B., Podsakoff, P. M., \& Fetter, R. (1993). The impact of organizational citizenship behavior on evaluations of salesperson performance. Journal of Marketing, 57(1), 70-80.doi: $10.1177 / 002224299305700105$

Oplatka, I. (2009). Organizational citizenship behavior in teaching. International Journal of Educational Management, 23(5), 375-389.doi: 10.1108/09513540910970476

Oplatka, I., \& Stundi, M. (2011). The components and determinants of preschool teacher organizational citizenship behavior. International Journal of Educational Management, 25(3), 223-236.doi: 10.1108/09513541111120079

Organ, D. W., \& Ryan, K. (1995). A meta-analytic review of attitudinal and dispositional predictors of organizational citizenship behavior. Personnel Psychology, 48(4), 775-802.doi: 10.1111/j.17446570.1995.tb01781.x

Organ, D. W. (1997). Organizational citizenship behavior: It's construct clean-up time. Human Performance, 10(2), 85-97.doi: 10.1207/s15327043hup1002_2

Organ, D. W. (1990a). The motivational basis of organizational citizenship behavior. Research in Organizational Behavior, 12(1), 43-72.doi: 10.1002/bs.3830090206

Organ, D. W. (1990b). The subtle significance of job satisfaction. Clinical Laboratory Management Review, 4(1), 94-98.doi: 10.1016/j.sbspro.2014.03.346

Organ, D.W. (1988), Organizational citizenship behavior: The good soldier syndrome. Lexington Books, Lexington. 
Organ, P., \& Podsakoff, P. M. MacKenzie. (2006). Organizational citizenship behavior: Its nature, antecedents, and consequences. Sage, Thousand Oaks, CA, 16, 43-44.

Podsakoff, P. M., MacKenzie, S. B., Moorman, R. H., \& Fetter, R. (1990). Transformational leader behaviors and their effects on followers' trust in leader, satisfaction, and organizational citizenship behaviors. The Leadership Quarterly, 1(2), 107-142.doi: 10.1016/1048-9843(90)90009-7

Podsakoff, P. M., MacKenzie, S. B., Paine, J. B.,\& Bachrach, D. G. (2000). Organizational citizenship behaviors: A critical review of the theoretical and empirical literature and suggestions for future research. Journal of Management, 26(3),513-563.doi: 10.1016/S0149-2063(00)00047-7

Rumberger, R. W., \& Thomas, S. L. (2000). The distribution of dropout and turnover rates among urban and suburban high schools. Sociology of education, 39-67.doi: 10.2307/2673198

Sesen, H., and Basim, N. H. (2012). Impact of satisfaction and commitment on teachers' organizational citizenship. Educational Psychology, 32(4), 475-491.

Smith, C. A., Organ, D. W., and Near, J. P. (1983). Organizational citizenship behavior: Its nature and antecedents. Journal of Applied Psychology, 68(4), 653.doi: 10.1037/0021-9010.68.4.653

Somech, A., \& Bogler, R. (2002). Antecedents and consequences of teacher organizational and professional commitment. Educational Administration Quarterly, 38(4), 555-577.

Somech, A., \& Oplatka, I. (2014). Organizational citizenship behavior in schools: Examining the impact and opportunities within educational systems. Routledge.

Spector, P. E. (1987). Method variance as an artifact in self-reported affect and perceptions at work: Myth or significant problem?. Journal of applied psychology, 72(3), 438.doi: 10.1037/0021-9010.72.3.438

Sweetland, S. R., \& Hoy, W. K. (2000). School characteristics and educational outcomes: Toward an organizational model of student achievement in middle schools. Educational Administration Quarterly, 36(5), 703-729.doi: 10.1177/00131610021969173

Turnipseed, D. L., \& Rassuli, A. (2005). Performance perceptions of organizational citizenship behaviors at work: A bi-level study among managers and employees. British Journal of Management, 16(3), 231-244.doi: 10.1111/j.1467-8551.2005.00456.x

Walz, S. M., \& Niehoff, B. P. (1996). Organizational citizenship behaviors and their effect on organizational effectiveness in limited-menu restaurants. Academy of Management Proceedings, Briarcliff Manor, New York, 1996, 307-311.

Williams, L. J., \& Anderson, S. E. (1991). Job satisfaction and organizational commitment as predictors of organizational citizenship and in-role behaviors. Journal of Management, 17(3), 601-617.doi: 10.1177/014920639101700305

Zeinabadi, H. (2010). Job satisfaction and organizational commitment as antecedents of organizational citizenship behavior (OCB) of teachers. Procedia-Social and Behavioral Sciences, 5, 998-1003.doi: 10.1016/j.sbspro.2010.07.225 